\title{
Specific anti-SARS-CoV-2 S1 IgY-scFv is a promising tool for recognition of the virus
}

\author{
Shikun Ge ${ }^{1,2}$, Rao Wu' ${ }^{1}$, Tingting Zhou ${ }^{4}$, Xiang Liu' ${ }^{1}$ Jin Zhu ${ }^{4}$ and Xiaoying Zhang ${ }^{1,2,3^{*}}$ (B)
}

\begin{abstract}
As severe acute respiratory syndrome coronavirus 2 (SARS-CoV-2) continues to spread globally, a series of vaccines, antibodies and drugs have been developed to combat coronavirus disease 2019 (COVID-19). High specific antibodies are powerful tool for the development of immunoassay and providing passive immunotherapy against SARSCoV-2 and expected with large scale production. SARS-CoV-2 S1 protein was expressed in E. coli BL21 and purified by immobilized metal affinity chromatography, as antigen used to immunize hens, the specific lgY antibodies were extracted form egg yolk by PEG-6000 precipitation, and the titer of anti-S1 IgY antibody reached 1:10,000. IgY single chain variable fragment antibody (IgY-scFv) was generated by using phage display technology and the IgY-scFv showed high binding sensitivity and capacity to S1 protein of SARS-CoV-2, and the minimum detectable antigen S1 protein concentration was $6 \mathrm{ng} / \mu \mathrm{L}$. The docking study showed that the multiple epitopes on the IgY-scFv interacted with multiple residues on SARS-CoV-2 S1 RBD to form hydrogen bonds. This preliminary study suggests that lgY and IgY-scFv are suitable candidates for the development of immunoassay and passive immunotherapy for COVID-19 to humans and animals.

Keywords: Coronavirus disease 2019 (COVID-19), Severe acute respiratory syndrome coronavirus 2 (SARS-CoV-2), Spike (S) protein S1 subunit, Egg yolk antibody (IgY), Chicken IgY single chain variable antibody fragment (IgY-scFv), $\lg Y$ technology
\end{abstract}

\section{Introduction}

COVID-19, first reported in December 2019, can cause pneumonia-like symptoms, including fever, cough and fatigue. There are no specific drugs available for COVID19 at present (Le Bert et al. 2020; Long et al. 2020). The pathogen, SARS-CoV-2, is positive-sense singlestranded RNA virus with a genome of approximately 30 $\mathrm{kbp}$ encodes four structural proteins, including spike, envelop, matrix and nucleocapsid (Kim et al. 2021). The spike (S) protein comprises two components: S1, which contains the distinct receptor binding domain (RBD); S2, which contains the fusion peptide. The viruses enter the host cells through the interaction of the RBD with host cell receptor angiotensin converting enzyme 2 (ACE2)

\footnotetext{
${ }^{*}$ Correspondence: zhang@bio.uminho.pt

${ }^{2}$ Centre of Molecular and Environmental Biology, Department of Biology, University of Minho, Campus de Gualtar, 4710-057 Braga, Portugal Full list of author information is available at the end of the article
}

(Wang et al. 2020). Antibodies against the S1 subunit, particularly targeting to RBD, are expected to prevent the viral particle surface protein from binding to the ACE2 receptor, thus preventing viral invasion (Parray et al. 2020). Therefore, the SARS-CoV-2 S1 protein has been accepted as ideal target for antibody and vaccine design (Premkumar et al. 2020; Parray et al. 2020). Furthermore, antibodies are the powerful tool for the development of point-of-care testing (POCT) immunoassay in SARS$\mathrm{CoV}-2$ analysis, the desired method should be accurate, specific, rapid, robust and inexpensive (Seo et al. 2020; Kim et al. 2021).

Apart from the routinely used IgG, IgY is the evolutionary precursor of IgG, avian sourced IgY antibodies can be also served as the counterpart of IgG, and the polyclonal IgY can be easily obtained in large quantities from hen egg yolk for broad biomedical purposes owning to a series of advantages such as higher productivity, better
Springer Open
C The Author(s) 2022. Open Access This article is licensed under a Creative Commons Attribution 4.0 International License, which permits use, sharing, adaptation, distribution and reproduction in any medium or format, as long as you give appropriate credit to the original author(s) and the source, provide a link to the Creative Commons licence, and indicate if changes were made. The images or other third party material in this article are included in the article's Creative Commons licence, unless indicated otherwise in a credit line to the material. If material is not included in the article's Creative Commons licence and your intended use is not permitted by statutory regulation or exceeds the permitted use, you will need to obtain permission directly from the copyright holder. To view a copy of this licence, visit http://creativecommons.org/licenses/by/4.0/. 
animal welfare, higher immunogenicity to mammal conserved proteins, lower cross-reactivity and not react with rheumatoid factors to avoid false positive results in immunoassay, as compared to the generation and application of mammalian full length monoclonal antibody (mAb) (Schade et al. 2007; Ge et al. 2020). Furthermore, in the recent decades, monoclonal IgY, particularly the IgY-scFv can be generated by using the phage display technology to better combine the biological superiorities of both IgY and recombinant antibody fragment (smaller size), is gaining increasing attention and application (Lee et al. 2017). The chicken monoclonal IgY-scFv has a high binding capacity to targeted pathogens (Chi et al. 2002; Wang et al. 2006; Pavoni et al. 2006), and it can overcome the difficulties in generating highly specific monoclonal antibodies (mAbs) from the traditional way of antibody generation, such as advantages of low cost and high yield (Groves and Morris 2000). Our previous studies demonstrated that IgY-scFv can be generated and applied in different immunoassays for the detection of small molecules gentamicin (Li et al. 2016) and large molecules CPV-VP2 (Ge et al. 2020) in the veterinary practice. It has been reported that $\mathrm{scFv}$ antibodies generated by using phage display technology has high neutralizing effect against SARS-CoV infection (Sui et al. 2004; Kang et al. 2006).

IgY have been extensively studied for the treatment of various respiratory viruses prior to the COVID-19 (Xiao et al. 2019), and IgY have also made some achievements in the treatment of pathogenic coronaviruses (Park and Iwasaki 2020), as early as in 2003 after the SARS epidemic, there was a research on IgY against SARS-CoV (Fu et al. 2006). In recent years, IgY antibodies have been developed and accessed targeting to coronavirus, the anti-MERS-CoV spike protein specific IgY have an efficient neutralization of virus infection in both in vitro and in vivo (El-Kafrawy et al. 2021), the specific IgY from hens immunized with inactivated SARS-CoV-2 had significant inhibitory against in vitro infections with live and pseudo typed SARS-CoV-2, and could stay in the upper airways for hours administered via oral spray or nasal drip (Shen et al. 2021).

This study aimed to generate and evaluate the IgY$\mathrm{scFv}$ against SARS-CoV-2 S1 protein, which may offer an alternative solution in providing large number of highlyspecific antibodies in combating COVID-19 in different application scenarios.

\section{Materials and methods}

\section{Preparation of SARS-CoV-2 S1 protein}

The full-length SARS-CoV-2 S1 gene (GenBank: QHD43416.1) was synthesized by Genscript Inc. (Nanjing, Jiangsu, China), and inserted between $B a m \mathrm{H}$ I and Not I restriction sites in a pET-28a $(+)$ plasmid (Novagen,
Beijing, China), transformed into E. coli (BL21, DE3) and induced overnight at room temperature using isopropyl$\beta$-D-thiogalactopyranoside (IPTG, $0.1 \mathrm{mM}$ ). Cells were collected by centrifugation and resuspended in phosphate buffered solution (PBS, $0.01 \mathrm{M}, \mathrm{pH}$ 7.4). After sonicated, the precipitates (inclusion bodies) were dissolved in PBS (containing $8 \mathrm{M}$ urea) and dialyzed against Tris$\mathrm{HCl}(20 \mathrm{mM}, \mathrm{pH} 7.4$, containing sequential dilutions of urea). The recombinant S1-6 $\times$ His protein was purified by immobilized metal affinity chromatography. Protein concentration was determined by OD absorbance at $280 \mathrm{~nm}$.

\section{Immunization of hens}

Three twelve-week-old white Leghorn hens were immunized intramuscularly with SARS-CoV-2 S1 protein mixed with Freund's adjuvant (Sigma-Aldrich, St. Louis, MO, USA) at five different sites of breast muscles. S1 protein $(250 \mu \mathrm{L}, 1 \mathrm{mg} / \mathrm{mL})$ in equal volume of normal saline was emulsified with Freund's complete adjuvant (FCA; Sigma-Aldrich, St. Louis, MO, USA) in the first immunization, and four booster immunizations were followed up with Freund's incomplete adjuvant (FIA; Sigma-Aldrich, St. Louis, MO, USA) at 2-week intervals in the breast muscles. All eggs were collected from the first immunization and were stored at $4{ }^{\circ} \mathrm{C}$ for future use. All experimental animal protocols were reviewed and approved by the institutional Ethics Committee for the use of laboratory animals.

\section{Generation of polyclonal lgY}

IgY antibody was extracted from egg yolk by polyethylene glycol (PEG) precipitation. Twice the egg yolk volume of PBS was mixed with the yolk, PEG-6000 (3.5\% w/v) were added to mixture and vortexed to remove lipids and lipoprotein, followed by $30 \mathrm{~min}$ rolling on a rolling mixer, and the mixture was centrifuged at $10,000 \mathrm{~g} 4{ }^{\circ} \mathrm{C}$ for $20 \mathrm{~min}$. The supernatant was poured through a filter and transferred to a new tube and PEG-6000 $(8.5 \% \mathrm{w} / \mathrm{v})$ was added to the tube, vortexed and rolled on a rolling mixer for $30 \mathrm{~min}$. The mixture was centrifuged to remove supernatant and the precipitation was carefully dissolved in $10 \mathrm{~mL}$ PBS, PEG-6000 (12\% w/v) was added into the tube on a rolling mixer for $30 \mathrm{~min}$, and the mixture was centrifuged, the precipitation was dissolved in $1.2 \mathrm{~mL}$ PBS and the mixture was dialyzed $24 \mathrm{~h}$ in PBS at $4{ }^{\circ} \mathrm{C}$. The IgY antibody extract was harvested from the dialysis capsule and transferred to $2 \mathrm{~mL}$ tube, stored at $-20^{\circ} \mathrm{C}$ for future use. SDS-PAGE and Western blot were conducted to evaluate the purity and specificity of the obtained IgY, and ELISA was performed to analyze antibody titer. 


\section{Assembly of IgY-scFv}

The spleen tissue from the hen with the highest IgY titer was collected to extract the total RNA by using Total RNA Kit (Tiangen Biotech, Beijing, China), and the firststrand cDNA was synthesized by HiScript Q Select RT SuperMix for PCR (Vazyme Biotech, Nanjing, China). The heavy variable fragment $\left(\mathrm{V}_{\mathrm{H}}\right)$ and light chain variable fragment $\left(\mathrm{V}_{\mathrm{L}}\right)$ genes were amplified by PCR with primers HF-Sf I and HR-Linker, LF-Linker and LR-Not I, respectively (Table 1). The $\mathrm{V}_{\mathrm{H}}$ and $\mathrm{V}_{\mathrm{L}}$ which both contained the sequence of a peptide linker were assembled to $\mathrm{scFv}$ with primers HF-Sf I and LR-Not I by Overlap PCR.

\section{Construction of IgY-scFv antibody library}

The scFv gene products were digested with $S f i$ I and Not I restriction enzyme and ligated to PCANTAB5E vector (Thermo Fisher Scientific, Waltham, MA, USA) by T4 DNA Ligase (NEB, Ipswich, MA, USA). The ligated products were transformed into E. coli TG1 cells and plated onto SOBAG plates (containing $2 \%$ tryptone, $0.5 \%$ yeast extract, $0.05 \% \mathrm{NaCl}, 2.5 \mathrm{mM} \mathrm{KCl}, 10 \mathrm{mM} \mathrm{MgCl}_{2}, 1.5 \%$ agar powder, $100 \mu \mathrm{g} / \mathrm{mL}$ ampicillin and $2 \%$ glucose), the plates were incubated overnight at $37^{\circ} \mathrm{C}$ to determine the scFv-TG1 library size and make the scFv-TG1 antibody library size reach more than $10^{6} \mathrm{pfu} / \mathrm{mL}$.

\section{Bio-panning of IgY-scFv antibody library}

Recombination phage library was generated in above scFv-TG1 library by the addition of helper phage M13KO7 (NEB, Ipswich, MA, USA), precipitated with polyethylene glycol 8000 (4\%, PEG-8000) and $\mathrm{NaCl}(3 \%$, $\mathrm{w} / \mathrm{v}$ ), and resuspended in $2 \mathrm{YT}$ medium and stored at $4{ }^{\circ} \mathrm{C}$. The bio-panning was carried out by adding $10^{12}$ plaque forming units $(\mathrm{pfu})$ of recombinant phages to wells pre-coated with $\mathrm{S} 1$ protein followed by incubation at $37^{\circ} \mathrm{C}$ for $2 \mathrm{~h}$. The unbound phages were removed by Tween-PBS (PBST), bound phages were eluted with $\mathrm{HCl}$-glycine $(\mathrm{pH} 2.5,0.2 \mathrm{M})$ with end-over-end mixing for $10 \mathrm{~min}$, the lower $\mathrm{pH}$ of the eluted phage neutralized with Tris- $\mathrm{HCl}(\mathrm{pH}$ 9.0) and used to infect the TG1 E. coli. The amplified phages were precipitated and recovered as described above for the next round of selection, and the bio-panning was repeated for three more times. The enrichment of specificity was determined from the input/output ratio of the phage. Phage-infected TG1 cells from each bio-panning were plated onto SOBAG plates to determine the library size. Ten random scFv-phage clones on the plates were selected from the fourth round to identify the positive rate and binding capacity to antigen by PCR and phage ELISA, respectively.

\section{Phage ELISA}

The binding capacity of scFv-phage suspensions to SARS-CoV-2 $\mathrm{S} 1$ protein were detected by phage ELISA. In detail, the bacteria solution $(50 \mu \mathrm{L})$ from each antibody phage library was inoculated into $2 \mathrm{YT}$ medium $(5 \mathrm{~mL})$ and cultured at $37^{\circ} \mathrm{C}$ for $3 \mathrm{~h}$ with shaking and transferred into of 2YT-AG medium $(5 \mathrm{~mL}$; containing $100 \mu \mathrm{g} / \mathrm{mL}$ ampicillin, $2 \%$ glucose) and M13KO7 phages were added. The above 2YT-AG medium was incubated at $37^{\circ} \mathrm{C}$ for $2.5 \mathrm{~h}$ at $150 \mathrm{rpm}$ in the shaker and then centrifuged at $1000 \mathrm{~g}$ for $15 \mathrm{~min}$ at $4{ }^{\circ} \mathrm{C}$. The precipitate was resuspended in 2 YT-AK $(400 \mu \mathrm{L})$ and cultured at $37^{\circ} \mathrm{C}$ overnight with shaking at $250 \mathrm{rpm}$ on the shaker. The bacterial culture solution was centrifuged and the supernatant was collected for phage ELISA analysis.

The wells of 96-well Maxisorp microtiter plate (Nunc, Roskilde, Denmark) were coated with $\mathrm{S} 1$ protein in carbonate buffer solution (CBS, $100 \mu \mathrm{L})$ overnight at $4{ }^{\circ} \mathrm{C}$ and then blocked with bovine serum albumin (BSA, $300 \mu \mathrm{L}$ ) for $2 \mathrm{~h}$ at $37^{\circ} \mathrm{C}$. The scFv-phage was added to each well for $2 \mathrm{~h}$ incubation at $37{ }^{\circ} \mathrm{C}$. The bound scFvphage was detected with horseradish peroxidase (HRP)conjugated anti-M13 antibody (Sino Biological, Beijing, China). The color was developed using TMB (Promega Biotech, Beijing, China) for $10 \mathrm{~min}$ and the absorbance was read at $450 \mathrm{~nm}$.

\section{Expression and purification of anti-SARS-CoV-2 S1 IgY-scFv protein}

The $\mathrm{scFv}$ with the highest binding capacity, as well as the corresponding pET-30a (+) vector, were digested by the BamH I and Hind III restriction enzyme (NEB, Ipswich, MA, USA), respectively, and the scFv was ligated into pET-30a (+) vector using the T4 DNA ligase (NEB, Ipswich, MA, USA). The positive recombinant plasmid was transformed into BL21 (DE3) and cultured in the LB medium (containing $1 \%$ tryptone, $0.5 \%$ yeast extract,

Table 1 Primers used for PCR

\begin{tabular}{lll}
\hline Name & Primer sequences (5'-3) & Application \\
\hline HF-Sfil & ATGTCTATGGCCCAGCCGGCCGTGACGTTGGACG & $V_{H}$ \\
HR-Linker & CAGAGCCACCTCCGCCTGAACCGCCTCCACCGGAGGAGACGATGACTTCGG & $V_{H}$ \\
LF-Linker & ITCAGGCGGAGGTGCTCTGGCGGTGGCGGATCGGCGCTGACTCAGCCGTCCT & $V_{L}$ \\
LR-NotI & AGTTACTGGAGCGGCCGCACCTAGGACGGTCAGGG & $V_{L}$ \\
\hline
\end{tabular}


$1 \% \mathrm{NaCl}$ and $100 \mu \mathrm{g} / \mathrm{mL}$ kanamycin) at $37{ }^{\circ} \mathrm{C}$. When the OD600 value reached $0.5-0.8$, the $\mathrm{scFv}$ proteins were induced by IPTG $(0.1 \mathrm{mM})$ for $8 \mathrm{~h}$ at $30^{\circ} \mathrm{C}$, the bacteria cells were collected by centrifuging at $12,000 \mathrm{~g}$ for $10 \mathrm{~min}$ and resuspended in PBS. The mixture was sonicated $(25 \%$ $\mathrm{W}$, working $3 \mathrm{~s}$ and pause $3 \mathrm{~s}$, total $15 \mathrm{~min}$ ) and centrifuged at $10,000 \mathrm{~g}$ for $10 \mathrm{~min}$ to collect the supernatant and sediment for SDS-PAGE analysis. The specificity of scFv was analyzed by Western blot.

\section{Analysis on IgY-scFv sensitivity by ELISA}

A 96-well Maxisorp microtiter plate (Nunc, Roskilde, Denmark) was coated with different amounts of SARSCoV-2 S1 protein $(0.1,0.2,0.4,0.6,0.8,1,5,8$ and $10 \mathrm{ng} /$ $\mu \mathrm{L})$ dissolved in CBS, and incubated overnight at $4{ }^{\circ} \mathrm{C}$, PBS was used as blank control (BC). The wells were rinsed with PBST ( 3 times $\times 5 \mathrm{~min}$ ) and incubated with different amounts of scFv protein $(0.2,0.6,1,5$ and $10 \mathrm{ng} /$ $\mu \mathrm{L}$ ) diluted in PBST for $1 \mathrm{~h}$ at $37^{\circ} \mathrm{C}$, PBS was used as negative control (NC). The wells were rinsed with PBST (3 times $\times 5 \mathrm{~min}$ ), and the mouse anti-His monoclonal IgG conjugated with HRP were added (1:5000, $100 \mu \mathrm{L} /$ well; CWBio, Beijing, China) and washed with PBST ( 3 times $\times 5 \mathrm{~min}$ ). The TMB (Promega Biotech, Beijing, China) was added to each well for $20 \mathrm{~min}$, and then the termination solution was added to read the absorbance at $450 \mathrm{~nm}$.

\section{Molecular modeling and scFv-S1 protein docking study}

Based on sequence identity/similarity homology, the SWISS-MODEL was used to build the molecular model of the scFv and RBD. Docking was performed by Discovery Studio 4.5 software (BIOVIA, San Diego, CA, USA), the scFv molecular model was docked with RBD using the ZDock Molecular Dock Program to obtain the docking conformation. The Residues Contact Frequency (RCF) algorithm was used to identify the most likely binding interface between scFv and RBD.

\section{Nucleotide data of the No.5 phage clone scFv}

The No.5 phage clone $\mathrm{scFv}$ gene sequence has been uploaded to the GenBank database (GenBank accession number: OL743524).

\section{Results}

\section{Evaluation of immunogen and polyclonal $\lg Y$}

SARS-CoV-2 S1 protein was expressed in a prokaryotic expression system and characterized (Fig. 1A). The antiS1 protein IgY was extracted and the SDS-PAGE gel indicated the light chain $(23 \mathrm{kDa})$ and heavy chain $(67 \mathrm{kDa})$ of IgY (Fig. 1B) (Pauly et al. 2009). The S1 protein could bind to specific IgY with a clear and specific single band (Fig. 1C). The specific IgY titer reached 1:10,000 (Fig. 1D).

\section{Construction of IgY-scFv library}

The length of $\mathrm{V}_{\mathrm{H}}$-linker, $\mathrm{V}_{\mathrm{L}}$-linker and $\mathrm{scFv}$ were approximately 420 bp, 370 bp, and 800 bp, respectively (Fig. 2A and $\mathrm{B})$. The titer of the primary anti-SARS-CoV-2 S1 scFv-TG1 library and the amplified M13KO7 phage scFv library were $3.2 \times 10^{6} \mathrm{pfu} / \mathrm{mL}$ and $2.8 \times 10^{13} \mathrm{pfu} / \mathrm{mL}$, respectively. Ninety-six percent of the phages contained the target fragments in the primary scFv-phage library.

\section{Bio-panning of IgY-scFv phage library}

The output of scFv-phage library was enriched 100 times in the fourth round as compared to the first round (Table 2), and the maximal ELISA binding signal was observed in the fourth round (Fig. 3). Ten randomly selected $\mathrm{scFv}$-phage clones from the fourth-round biopanning, in phage ELISA, each scFv-phage clone sample showed high binding activity against $\mathrm{S} 1$ protein, The No.5 scFv-phage showed the highest binding capacity and was chosen for further experiments (Fig. 4). All of the 10 clones contained expected scFv DNA sequences of about $800 \mathrm{bp}$ (Fig. 5), and all the $10 \mathrm{scFv}$ genes have complementary determining region $3(\mathrm{CDR} 3)$ that was the main mutation region in both $\mathrm{V}_{\mathrm{H}}$ and $\mathrm{V}_{\mathrm{L}}$ (Fig. 6).

\section{Evaluation of polyclonal IgY-scFv}

The $\mathrm{scFv}$ of No.5 phage clone was used for subsequent expression. The His-tagged $\mathrm{scFv}$ was overexpressed in an $E$. coli system, a band of estimated molecular mass of $38 \mathrm{kDa}$ was detected on SDS-PAGE (Fig. 7A). The solubility analysis indicated that the expressed $\mathrm{scFv}$ protein existed as inclusion body (Fig. 7A), the denaturation and purification of $\mathrm{scFv}$ inclusion body protein showed a single protein band with $>95 \%$ purity (Fig. 7A). The scFv bound in a dose-dependent manner to the soluble S1 (Fig. 7B) in ELISA, and the minimum detectable antigen S1 protein concentration was $6 \mathrm{ng} / \mu \mathrm{L}$.

\section{Interaction between IgY-scFv and SARS-CoV-2 S1}

$\mathrm{ScFv}$-RBD docking identified the interacted hot-spot residues. The ASP87, ARG90, GLN91, THR97, LYS99, ILE100 and TYR103 of scFv contributed significantly to the formation of hydrogen bonds with residues GLY159, SER161, ASN183, GLY200 and SER225 of RBD, respectively (Fig. 8D). These epitopes are primarily located in the CDR3 domain of the IgY-scFv. Structure-based rational design of $\mathrm{scFv}$ with binding capacity to $\mathrm{S} 1$ protein may facilitate development of neutralizing antibodies (nAbs) for the suppression of viral infection.

\section{Discussion}

The world has invested an unprecedented amount of resources to achieve a common goal of controlling and eradicating SARS-CoV-2. Specific antibodies are 

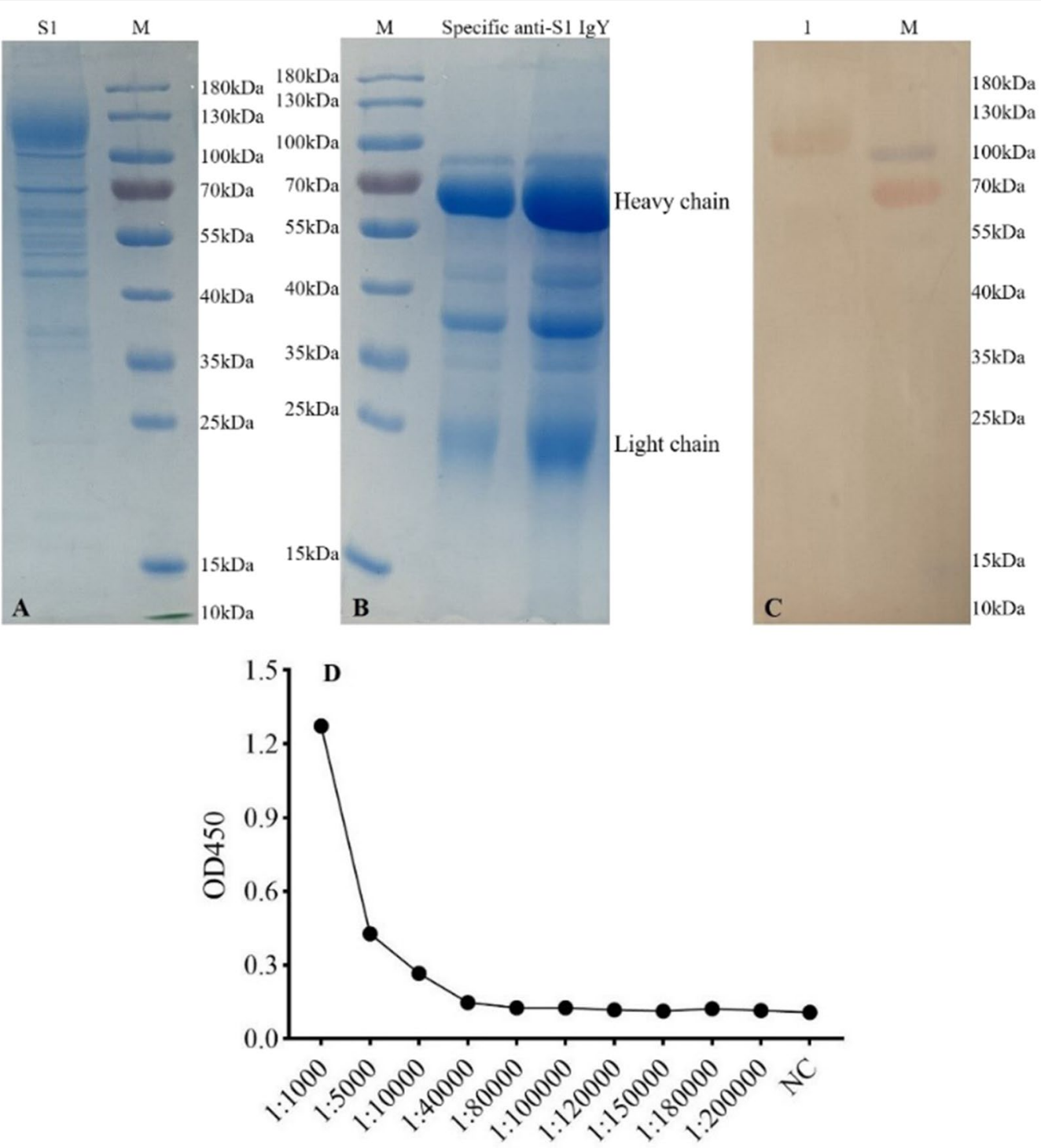

$\operatorname{IgY}$ antibody dilution

Fig. 1 Characteristics of the S1 proteien and specific anti-S1 IgY antibody. A SDS-PAGE analysis of the S1 proteien. B SDS-PAGE analysis of the specific anti-S1 IgY antibody. C Western blot analysis of the specific IgY antibody. Lane 1, antigen was S1 protein, incubated with primary antibody lgY. D the analysis of the specific lgY antibody titer; Negative control sample (NC): PBS; Statistical principle, P/N > 2.0 (P, samples value; N, NC value), results are means of three replicates. M, Pre-stained Protein Ladder (Thermo Fisher Scientific, Waltham, MA, USA). The secondary antibody, goat anti-chicken $\lg$ Y H\&L (HRP) (Abcam, Cambridge, UK)

powerful tools for SARS-CoV-2 immunoassay analysis and providing passive immunization to tackling the infection (Casadevall and Pirofski 2020).

A series of anti-SARS-CoV-2 antibodies and vaccines have been being developed emergently. Several major anti-spike protein mammalian mAbs, S309/S2E12, 2B04/47D11, COV2-2130/COV2-2196, REGN10933/ REGN10987 and LY-CoV555, were evaluated for their protective efficacy for Emergency Use Authorization
(EUA). Limited data indicated that a combined therapy of several antibodies (S309/S2E12, COV2-2130/COV22196 and REGN10933/REGN10987) conferred better protection, as compared to the cases when the antibodies were applied solely (Chen et al. 2021; Gottlieb et al. 2021), this highlights the importance that we may need a toolbox of diversified antibodies and cocktail approach by targeting to distinct epitopes and mutants in order to achieve the best composite effect of therapy 

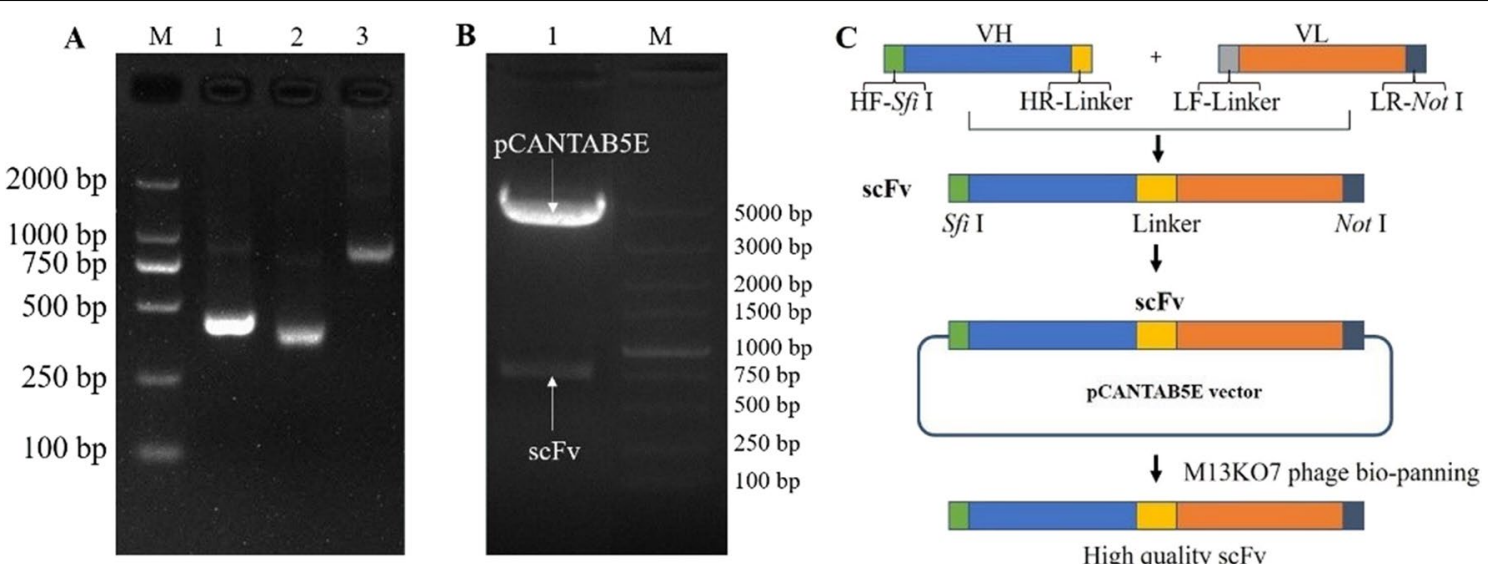

Fig. 2 Construction of the lgY-scFv antibody phage display library. A PCR products of $V_{H}\left(420 \mathrm{bp}\right.$, lane 1), $V_{L}(370 \mathrm{bp}$, lane 2 ) and scFv (800 bp, lane 3). B Double restriction digestion result of pCANTAB5E-scFv recombinant plasmid. C Schematic diagram of scFv construction. M: DNA marker (TaKaRa, Dalian, China)

Table 2 Library sizes and phage titers of each bio-panning

\begin{tabular}{lllll}
\hline Round & $\begin{array}{l}\text { Coating concentration (per } \\
\text { well) }\end{array}$ & Input (pfu/mL) & Output (pfu/mL) & $\begin{array}{l}\text { Amplification } \\
\text { library (pfu/ } \\
\mathrm{mL})\end{array}$ \\
\hline 1 & $15 \mu \mathrm{g}$ & $1 \times 10^{12}$ & $5.6 \times 10^{6}$ & $5.14 \times 10^{12}$ \\
2 & $10 \mu \mathrm{g}$ & $1 \times 10^{11}$ & $7.2 \times 10^{6}$ & $7.2 \times 10^{12}$ \\
3 & $10 \mu \mathrm{g}$ & $1 \times 10^{11}$ & $2.8 \times 10^{8}$ & $3.88 \times 10^{12}$ \\
4 & $5 \mu \mathrm{g}$ & $1 \times 10^{11}$ & $6.6 \times 10^{8}$ & - \\
\hline
\end{tabular}

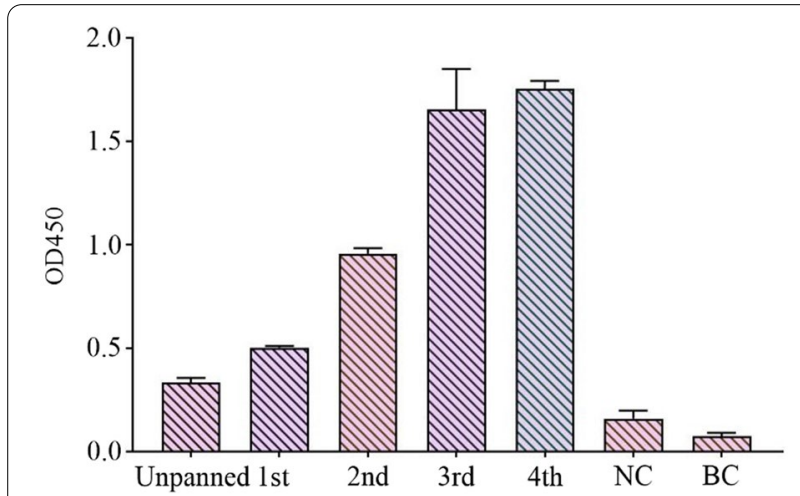

Fig. 3 ELISA for 4 rounds of bio-panning phage library. Samples from round 1-4, phage in each of 4 rounds of bio-panning procedure. Unpanned sample: the primary scFv phage library. Negative control sample (NC): PBS. Blank control sample (BC): CBS

and prevention in the future. The VHH nanobodies from dromedary camels by phage display have high affinity for the RBD and broad neutralization activities against SARS-CoV-2, efficiently protects transgenic mice from the lethal challenge of virus (Hong et al. 2021). However, although the polyclonal human IgG

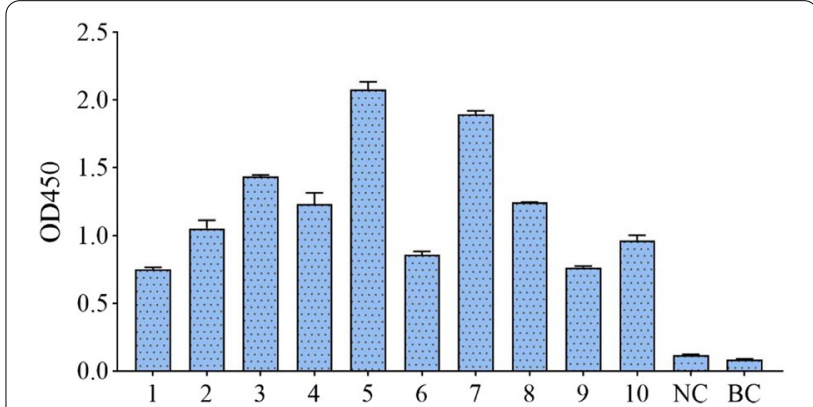

Fig. 4 Reactivity of IgY-scFv to S1 protein analyzed by phage ELISA. $1-10$, scFv antibodies from randomly selected clones from the fourth bio-panning. Negative control sample (NC), PBS. Blank control sample (BC), CBS

(SAB-185) can protecte the human ACE2 transgenic Syrian hamster model from fatal disease and minimized clinical signs of infection, a control convalescent human serum sample was less effective at neutralizing the variant (Gilliland et al. 2021).

Here, we are providing alternative and novel solutions in generating avian sourced anti-SARS-CoV-2 polyclonal IgY, and more importantly, developing IgY-scFv 


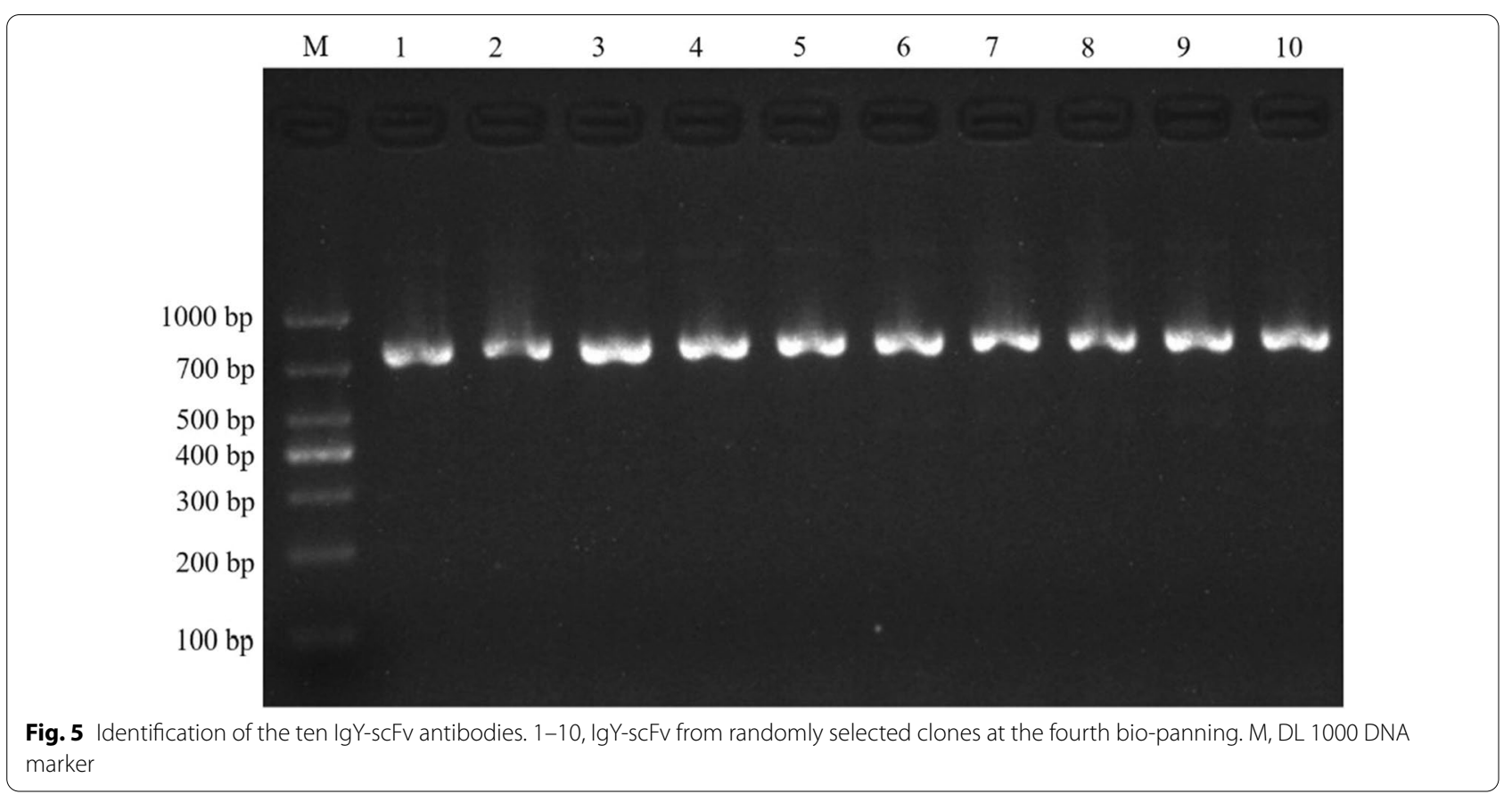

antibodies by using $M 13 K O 7$ phage display technology, with the $\mathrm{S} 1$ protein as antigen.

As discussed recently, immunizing chickens with recombinant S1 protein can produce IgY neutralizing antibodies against the SARS-CoV-2 spike protein S1 subunit, and the production of large amounts of IgY that inhibits SARS-CoV-2 virus binding and replication is feasible for incorporation into an intranasal spray and/ or other mucosal protection products may be effective at reducing infection and spread of COVID-19 (Artman et al. 2021; Bao et al. 2021). The large phylogenetic distance between mammals and birds allow IgY antibodies to recognize certain mammalian conserved protein epitopes (Hädge et al. 1980; Zhang et al. 2017; Pérez de la Lastra et al; 2020). The neutralized IgY antibodies, particularly the polyclonal IgY, as a potential passive immunization intervention against infections of emerging pathogens, including SARS-CoV-2, and safely used as a nasal, oral spray and gargle. In addition, IgY does not interact with mammalian Fc receptors or activate the mammalian complement system, so it can avoid triggering antibody-dependent enhancement (ADE) of disease and complement-mediated adverse inflammatory responses (Kovacs-Nolan and Mine 2012), therefore, it could be beneficial to administer neutralizing IgY (or, after genetic modification) intravascularly to treat SARS-CoV-2 infection (Lee et al. 2010; Lu et al. 2020). In this study, the chicken polyclonal IgY prepared can significantly inhibit the entry of SARS-CoV-2 virus into cells in vitro (Data not shown, Chinese Patent No.
CN113402603A). The global effort to prevent SARS$\mathrm{CoV}-2$ infections will have to continue for some period, IgY antibodies from hen egg yolk could be a good alternative because of their viability for large-scale commercial production and the relative non-invasive methods used to prepare them.

In this study, the IgY-scFv bound to $\mathrm{S} 1$ protein efficiently and sensitively, and the minimum detectable antigen $\mathrm{S} 1$ protein concentration was $6 \mathrm{ng} / \mu \mathrm{L}$ (Fig. 7). The docking study suggested that the multiple interacted epitopes on the IgY-scFv (Fig. 8) were primarily located in the CDR3 domain. Our IgY-scFv as a parameter can be considered as the mode of humanization for better improvement (Nishibori et al. 2006), and various studies have been reported that the use of chimeric chicken IgY$\mathrm{scFv}$ antibodies can be extended further to other mammalian species in human and veterinary applications (Tsurushita et al. 2004; Schusser et al. 2013).

This study is the first attempt to generate and characterize anti-SARS-CoV-2 avian highly specific IgY-scFv. Due to the restriction and difficulty in accessing SARS$\mathrm{CoV}-2$ virus and clinical samples, we were not able to further validate the obtained IgY-scFv in virus and animal models. However, as a pilot study, our work offers a possibility that the obtained IgY-scFv could be referenced as a parent structure for further antibody design in order to achieve better neutralization capacity to effectively block the SARS-CoV-2 infection. Furthermore, this IgY$\mathrm{scFv}$ structure can be used for further engineering and optimization, which allows not only efficient mutation 


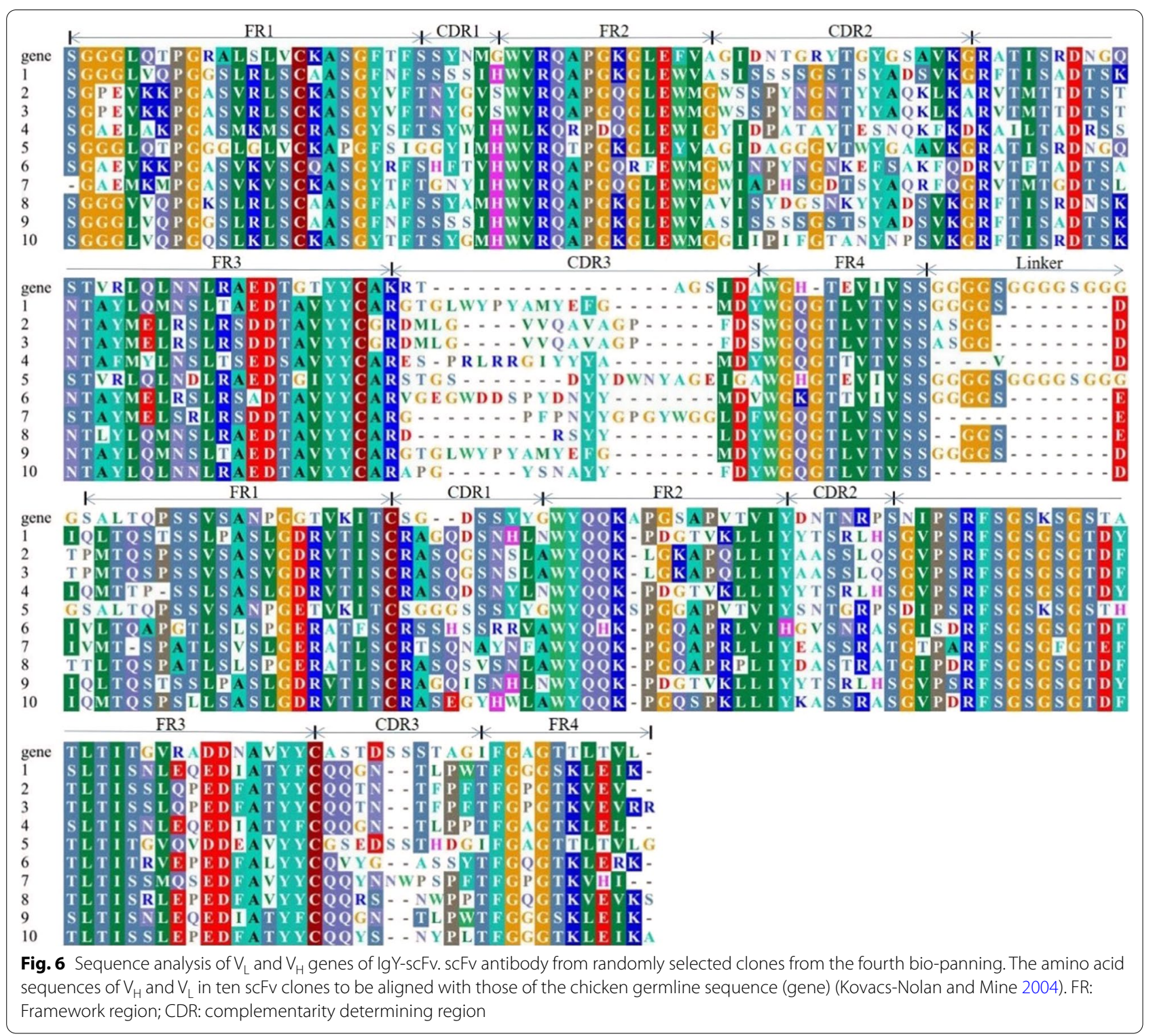

of antibody fragments with higher affinity to antigen, but also generation of functional antibody mimics/peptidomimetics for improved immunoassay and therapy (Baloch et al. 2016; Ge et al. 2020, 2021).
Anti-SARS-CoV-2 IgY-scFv and IgY antibodies were generated. The obtained IgY-scFv showed high binding sensitivity and binding capacity to the S1 protein, and the multiple epitopes on the IgY-scFv interact with 


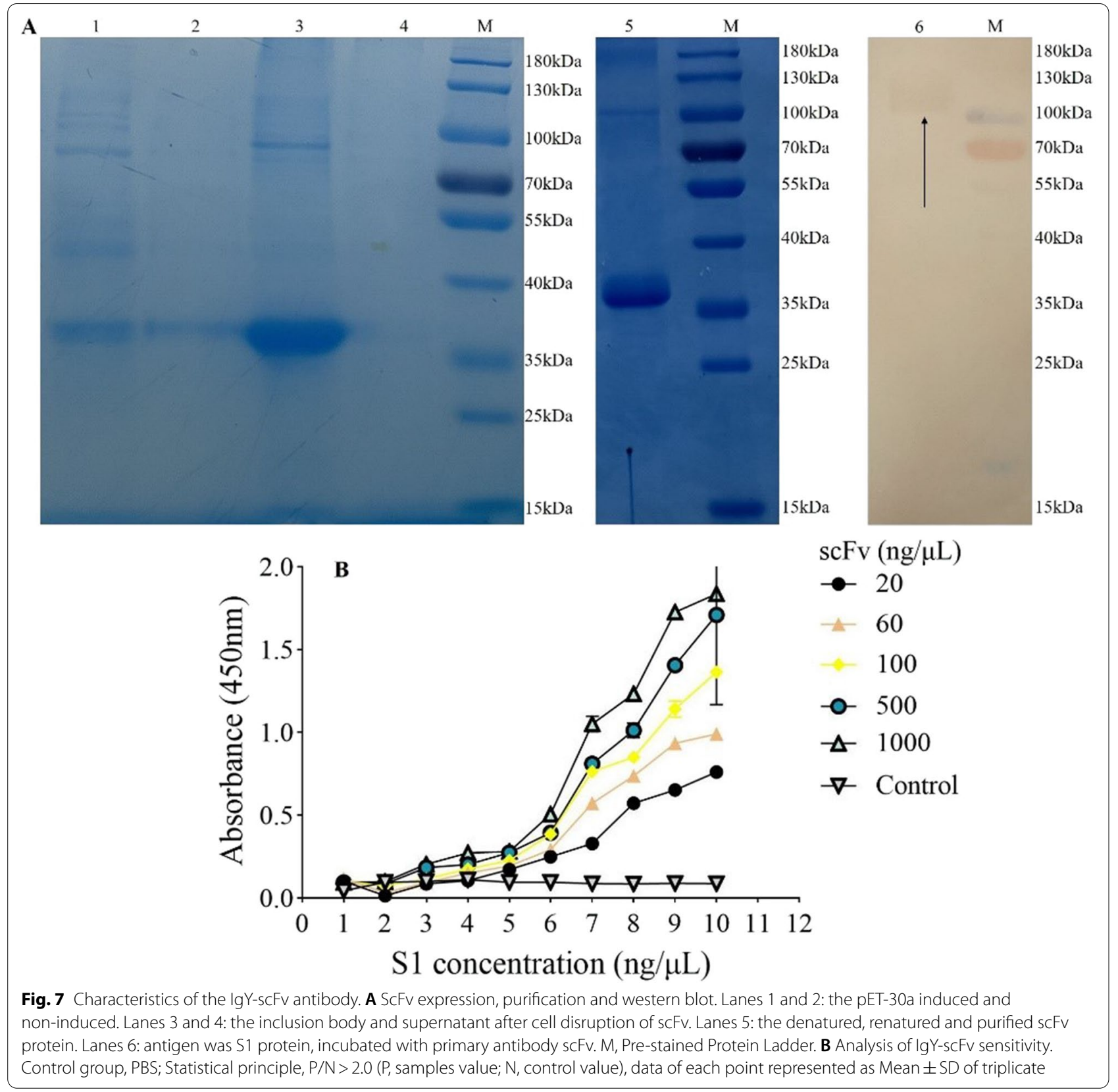

multiple residues on SARS-CoV-2 spike protein RBD to form hydrogen bonds, these epitopes are primarily located in the CDR3 domain of the IgY-scFv. The
IgY-scFv together with the polyclonal IgY we obtained, these antibodies could be applied for different biomedical scenarios in fighting against COVID-19 than mammalian antibodies. 


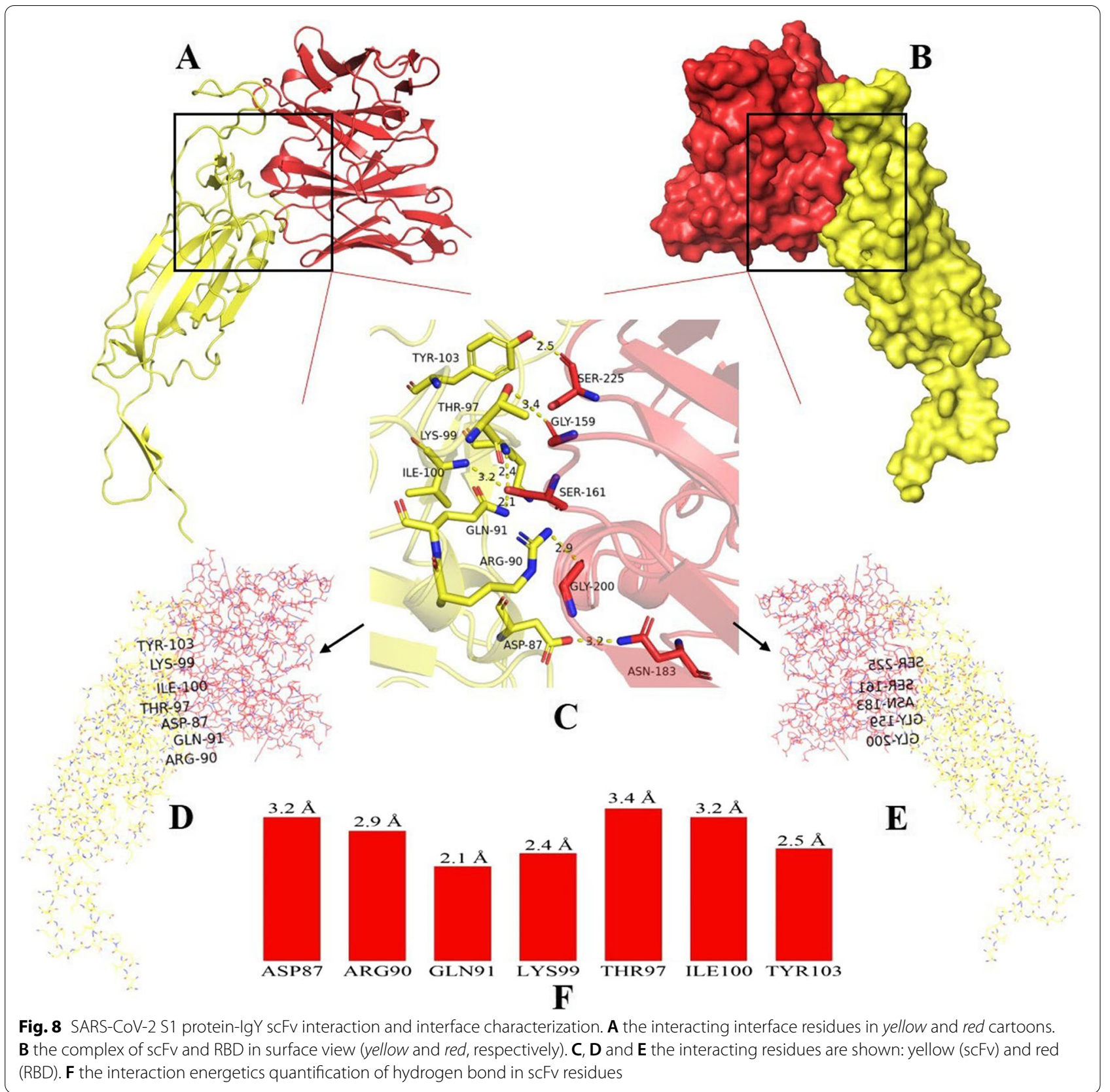

\section{Abbreviations}

COVID-19: Coronavirus disease 2019; SARS-CoV-2: Severe acute respiratory syndrome coronavirus 2; ACE2: Angiotensin converting enzyme 2; RBD: Receptor binding domain; IgY-scFv: Chicken IgY single chain variable fragment antibody; S: Spike protein; nAbs: Neutralizing antibodies; IPTG: Isopropyl $\beta$-D1thiogalactopyranoside; PBS: Phosphate buffered solution; RT-PCR: Real-time polymerase chain reaction; POCT: Point-of-care testing; mAb: Monoclonal antibody; VH: Heavy variable fragment; VL: Light chain variable fragment; RCF: Residues contact frequency; CDR3: Complementary determining region 3; pfu: Plaque forming units; EUA: Emergency Use Authorization; ADE: Antibodydependent enhancement.

\section{Acknowledgements}

Not applicable.

\section{Authors' contributions}

XYZ and JZ conceived and designed research. SKG, RW TTZ and XL conducted experiments. SKG analyzed data and wrote the manuscript. All authors read and approved the manuscript.

\section{Funding}

This work was supported by the National Natural Science Foundation of China (31873006, 31572556).

\section{Availability of data and materials}

All data generated or analyzed during this study are included in this published article. 


\section{Declarations}

\section{Ethics approval and consent to participate}

All experimental animal protocols were reviewed and approved by the institutional Committee of Shaanxi University of Technology for the use of laboratory animals (Approval Number 2020-06, Chinese-German Joint Institute for Natural Product Research).

\section{Consent for publication}

Not applicable.

\section{Competing interests}

The authors declare that they have no competing interests for this article.

\section{Author details}

${ }^{1}$ School of Biological Science and Engineering, Shaanxi University of Technology, Hanzhong, China. ${ }^{2}$ Centre of Molecular and Environmental Biology, Department of Biology, University of Minho, Campus de Gualtar, 4710-057 Braga, Portugal. ${ }^{3}$ Department of Biomedical Sciences, Ontario Veterinary College, University of Guelph, Guelph, ON, Canada. ${ }^{4}$ Huadong Medical Institute of Biotechniques, Nanjing, Jiangsu, China.

Received: 7 December 2021 Accepted: 26 January 2022

Published online: 12 February 2022

\section{References}

Artman C, Brumfield KD, Khanna S, Goepp J (2021) Avian antibodies (IgY) targeting spike glycoprotein of severe acute respiratory syndrome coronavirus 2 (SARS-CoV-2) inhibit receptor binding and viral replication. PLoS ONE 16(5):e0252399

Baloch AR, Baloch AW, Sutton BJ, Zhang X (2016) Antibody mimetics: promising complementary agents to animal-sourced antibodies. Crit Rev Biotechnol 36(2):268-275

Bao L, Zhang C, Lyu J, Yi P, Shen X, Tang B, Zhao H, Ren B, Kuang Y, Zhou L, Li Y (2021) Egg yolk immunoglobulin (lgY) targeting SARS-CoV-2 S1 as potential virus entry blocker. J Appl Microbiol. https://doi.org/10.1111/ jam. 15340

Casadevall A, Pirofski LA (2020) The convalescent sera option for containing COVID-19. J Clin Invest 130(4):1545-1548

Chen RE, Winkler ES, Case JB, Aziati ID, Bricker TL, Joshi A, Darling TL, Ying B, Errico JM, Shrihari S, VanBlargan LA, Xie X, Gilchuk P, Zost SJ, Droit L, Liu Z, Stumpf S, Wang D, Handley SA, Stine WB Jr, Shi PY, Davis-Gardner ME, Suthar MS, Knight MG, Andino R, Chiu CY, Ellebedy AH, Fremont DH, Whelan SPJ, Crowe JE Jr, Purcell L, Corti D, Boon ACM, Diamond MS (2021) In vivo monoclonal antibody efficacy against SARS-CoV-2 variant strains. Nature 596(7870):103-108

Chi XS, Landt Y, Crimmins DL, Dieckgraefe BK, Ladenson JH (2002) Isolation and characterization of rabbit single chain antibodies to human Reg lalpha protein. J Immunol Methods 266(1-2):197-207

El-Kafrawy SA, Abbas AT, Sohrab SS, Tabll AA, Hassan AM, Iwata-Yoshikawa N, Nagata N, Azhar El (2021) Immunotherapeutic efficacy of IgY antibodies targeting the full-length spike protein in an animal model of middle east respiratory syndrome coronavirus infection. Pharmaceuticals 14(6):511

Fu CY, Huang H, Wang XM, Liu YG, Wang ZG, Cui SJ, Gao HL, Li Z, Li JP, Kong XG (2006) Preparation and evaluation of anti-SARS coronavirus IgY from yolks of immunized SPF chickens. J Virol Methods 133(1):112-115

Ge S, Xu L, Li B, Zhong F, Liu X, Zhang X (2020) Canine Parvovirus is diagnosed and neutralized by chicken IgY-scFv generated against the virus capsid protein. Vet Res 51(1):110

Ge S, Zhang X, Zhong F, Liu X, Zhang X (2021) Generation and evaluation of IgY-scFv based mimetics against canine parvovirus. Vet Res 52(1):70

Gilliland T., Y. Liu, R. Li, M. Dunn, E. Cottle, Y. Terada, Z. Ryckman, M. Alcorn, S. Vasilatos, J. Lundy, D. Larson, H. Wu, T. Luke, C. Bausch, K. Egland, E. Sullivan, Z. Wang, W. B. Klimstra (2021) Protection of human ACE2 transgenic Syrian hamsters from SARS CoV-2 variants by human polyclonal lgG from hyper-immunized transchromosomic bovines. bioRxiv. 26:2021.07.26.

Gottlieb RL, Nirula A, Chen P, Boscia J, Heller B, Morris J, Huhn G, Cardona J, Mocherla B, Stosor V, Shawa I, Kumar P, Adams AC, Van Naarden J,
Custer KL, Durante M, Oakley G, Schade AE, Holzer TR, Ebert PJ, Higgs RE, Kallewaard NL, Sabo J, Patel DR, Klekotka P, Shen L, Skovronsky DM (2021) Effect of bamlanivimab as monotherapy or in combination with etesevimab on viral load in patients with mild to moderate COVID-19: a randomized clinical trial. JAMA 325(7):632-644

Groves DJ, Morris BA (2000) Veterinary sources of nonrodent monoclonal antibodies: interspecific and intraspecific hybridomas. Hybridoma 19(3):201-214

Hädge D, Fiebig H, Puskas E, Ambrosius H (1980) Evolution of low molecular weight immunoglobulins. II. No antigenic cross-reactivity of human IgD, human IgG and IgG3 to chicken IgY. Dev Comp Immunol 4(4):725-736

Hong J., H. J. Kwon, R. Cachau, C. Z. Chen, K. J. Butay, Z. Duan, D. Li, H. Ren, T. Liang, J. Zhu, V. P. Dandey, N. Martin, D. Esposito, U. Ortega-Rodriguez, M. Xu, M. J. Borgnia, H. Xie, M. Ho (2021) Camel nanobodies broadly neutralize SARS-CoV-2 variants. bioRxiv. 29:2021.10.27.465996.

Kang X, Yang BA, Hu Y, Zhao H, Xiong W, Yang Y, Si B, Zhu Q (2006) Human neutralizing Fab molecules against severe acute respiratory syndrome coronavirus generated by phage display. Clin Vaccine Immunol 13(8):953-957

Kim HY, Lee JH, Kim MJ, Park SC, Choi M, Lee W, Ku KB, Kim BT, Changkyun Park E, Kim HG, Kim SI (2021) Development of a SARS-CoV-2-specific biosensor for antigen detection using scFv-Fc fusion proteins. Biosens Bioelectron 175:112868

Kovacs-Nolan J, Mine Y (2004) Avian egg antibodies: basic and potential applications. Avian Poult Biol Rev. https://doi.org/10.3184/1470206047 83637462

Kovacs-Nolan J, Mine Y (2012) Egg yolk antibodies for passive immunity. Annu Rev Food Sci Technol 3:163-182

Le Bert N, Tan AT, Kunasegaran K, Tham CYL, Hafezi M, Chia A, Chng MHY, Lin M, Tan N, Linster M, Chia WN, Chen MI, Wang LF, Ooi EE, Kalimuddin S, Tambyah PA, Low JG, Tan YJ, Bertoletti A (2020) SARS-CoV-2-specific T cell immunity in cases of COVID-19 and SARS, and uninfected controls. Nature 584(7821):457-462

Lee BS, Huang JS, Jayathilaka GD, Lateef SS, Gupta S (2010) Production of antipeptide antibodies. Methods Mol Biol 657:93-108

Lee W, Syed Atif A, Tan SC, Leow CH (2017) Insights into the chicken IgY with emphasis on the generation and applications of chicken recombinant monoclonal antibodies. J Immunol Methods 447:71-85

Li C, He J, Ren H, Zhang X, Du E, Li X (2016) Preparation of a chicken scFv to analyze gentamicin residue in animal derived food products. Anal Chem 88(7):4092-4098

Long QX, Liu BZ, Deng HJ, Wu GC, Deng K, Chen YK, Liao P, Qiu JF, Lin Y, Cai XF, Wang DQ, Hu Y, Ren JH, Tang N, Xu YY, Yu LH, Mo Z, Gong F, Zhang XL, Tian WG, Hu L, Zhang XX, Xiang JL, Du HX, Liu HW, Lang CH, Luo XH, Wu SB, Cui XP, Zhou Z, Zhu MM, Wang J, Xue CJ, Li XF, Wang L, Li ZJ, Wang K, Niu CC, Yang QJ, Tang XJ, Zhang Y, Liu XM, Li JJ, Zhang DC, Zhang F, Liu P, Yuan J, Li Q, Hu JL, Chen J, Huang AL (2020) Antibody responses to SARSCoV-2 in patients with COVID-19. Nat Med 26(6):845-848

Lu Y, Wang Y, Zhang Z, Huang J, Yao M, Huang G, Ge Y, Zhang P, Huang H, Wang Y, Li H, Wang W (2020) Generation of chicken IgY against SARSCOV-2 spike protein and epitope mapping. J Immunol Res 2020:9465398

Nishibori N, Horiuchi H, Furusawa S, Matsuda H (2006) Humanization of chicken monoclonal antibody using phage-display system. Mol Immunol 43(6):634-642

Park A, Iwasaki A (2020) Type I and type III interferons - induction, signaling, evasion, and application to combat COVID-19. Cell Host Microbe 27(6):870-878

Parray HA, Chiranjivi AK, Asthana S, Yadav N, Shrivastava T, Mani S, Sharma C, Vishwakarma P, Das S, Pindari K, Sinha S, Samal S, Ahmed S, Kumar R (2020) Identification of an anti-SARS-CoV-2 receptor-binding domaindirected human monoclonal antibody from a naïve semisynthetic library. J Biol Chem 295(36):12814-12821

Pauly D, Dorner M, Zhang X, Hlinak A, Dorner B, Schade R (2009) Monitoring of laying capacity, immunoglobulin $Y$ concentration, and antibody titer development in chickens immunized with ricin and botulinum toxins over a two-year period. Poult Sci 88(2):281-290

Pavoni E, Flego M, Dupuis ML, Barca S, Petronzelli F, Anastasi AM, D'Alessio V, Pelliccia A, Vaccaro P, Monteriù G, Ascione A, De Santis R, Felici F, Cianfriglia M, Minenkova O (2006) Selection, affinity maturation, and characterization of a human sCFv antibody against CEA protein. BMC Cancer 6:41 
Pérez de la Lastra JM, Baca-González V, Asensio-Calavia P, González-Acosta S, Morales-delaNuez A (2020) Can immunization of hens provide oral-based therapeutics against COVID-19? Vaccines 8(3):486

Premkumar L, Segovia-Chumbez B, Jadi R, Martinez DR, Raut R, Markmann A, Cornaby C, Bartelt L, Weiss S, Park Y, Edwards CE, Weimer E, Scherer EM, Rouphael N, Edupuganti S, Weiskopf D, Tse LV, Hou YJ, Margolis D, Sette A, Collins MH, Schmitz J, Baric RS, de Silva AM (2020) The receptor binding domain of the viral spike protein is an immunodominant and highly specific target of antibodies in SARS-CoV-2 patients. Sci Immunol 5(48):eabc8413

Schade R, Zhang XY, Horacio Raúl T (2007) Use of IgY antibodies in human and veterinary medicine, vol 25. Springer, Berlin, pp 213-222

Schusser B, Yi H, Collarini EJ, Izquierdo SM, Harriman WD, Etches RJ, Leighton PA (2013) Harnessing gene conversion in chicken B cells to create a human antibody sequence repertoire. PLOS ONE 8(11):e80108

Seo G, Lee G, Kim MJ, Baek SH, Choi M, Ku KB, Lee CS, Jun S, Park D, Kim HG, Kim SJ, Lee JO, Kim BT, Park EC, Kim SI (2020) Rapid detection of COVID-19 causative virus (SARS-CoV-2) in human nasopharyngeal swab specimens using field-effect transistor-based biosensor. ACS Nano 14(4):5135-5142

Shen $\mathrm{H}$, Cai Y, Zhang H, Wu J, Ye L, Yang P, Lin X, Jiang S, Liao M (2021) Anti-SARS-CoV-2 lgY isolated from egg yolks of hens immunized with inactivated SARS-CoV-2 for immunoprophylaxis of COVID-19. Virol Sin 36(5):1080-1082

Sui J, Li W, Murakami A, Tamin A, Matthews LJ, Wong SK, Moore MJ, Tallarico AS, Olurinde M, Choe H, Anderson LJ, Bellini WJ, Farzan M, Marasco WA (2004) Potent neutralization of severe acute respiratory syndrome (SARS) coronavirus by a human $\mathrm{mAb}$ to $\mathrm{S} 1$ protein that blocks receptor association. Proc Natl Acad Sci USA 101(8):2536-2541

Tsurushita N, Park M, Pakabunto K, Ong K, Avdalovic A, Fu H, Jia A, Vásquez M, Kumar S (2004) Humanization of a chicken anti-IL-12 monoclonal antibody. J Immunol Methods 295(1-2):9-19

Wang SH, Zhang JB, Zhang ZP, Zhou YF, Yang RF, Chen J, Guo YC, You F, Zhang XE (2006) Construction of single chain variable fragment (ScFv) and BiscFv-alkaline phosphatase fusion protein for detection of Bacillus anthracis. Anal Chem 78(4):997-1004

Wang C, Li W, Drabek D, Okba NMA, van Haperen R, Osterhaus A, van Kuppeveld FJM, Haagmans BL, Grosveld F, Bosch BJ (2020) A human monoclonal antibody blocking SARS-CoV-2 infection. Nat Commun 11(1):2251

Xiao Y, Hu Q, Jiao L, Cui X, Wu P, He P, Xia N, Lv R, Liang Y, Zhao S (2019) Production of anti-trichophyton rubrum egg yolk immunoglobulin and its therapeutic potential for treating dermatophytosis. Microb Pathog 137:103741

Zhang X, Calvert RA, Sutton BJ, Doré KA (2017) IgY: a key isotype in antibody evolution. Biol Rev Camb Philos Soc 92(4):2144-2156

\section{Publisher's Note}

Springer Nature remains neutral with regard to jurisdictional claims in published maps and institutional affiliations.

\section{Submit your manuscript to a SpringerOpen ${ }^{\circ}$ journal and benefit from:}

- Convenient online submission

- Rigorous peer review

- Open access: articles freely available online

- High visibility within the field

- Retaining the copyright to your article 